\title{
Hubungan Tingkat Kecukupan Zat Besi Dan Seng Dengan Kejadian Stunting Pada Balita 6-23 Bulan
}

\section{Correlation Between Iron and Zinc Adequacy Level With Stunting Incidence In Children Aged 6 -23 Months}

\author{
Enggar Kartika Dewi ${ }^{* 1}$, Triska Susila Nindya $^{1}$
}

\begin{abstract}
ABSTRAK
Latar Belakang: Stunting merupakan masalah gizi akibat kekurangan gizi jangka panjang yang berdampak pada pertumbuhan linier. Salah satu zat gizi mikro yang erat kaitannya dengan stunting adalah zat besi dan seng, sebab kedua zat mikro tersebut memiliki peran penting dalam pertumbuhan linier balita 6-23 bulan.

Tujuan: Tujuan dari penelitian ini adalah untuk menganalisis hubungan tingkat asupan zat besi dan seng dengan kejadian stunting pada balita 6-23 Bulan.

Metode: Penelitian ini merupakan jenis penelitian observasional analitik dengan desain penelitian cross sectional. Sampel terdiri dari 55 anak yang tersebar di 25 Posyandu di Desa Suci. Pengumpulan data menggunakan food recall $3 \times 24$ jam, pengukuran tinggi badan dengan mikrotoa untuk mengetahui status stunting, dan kuesioner karakteristik anak dan ibu. Data dianalisis menggunakan uji Fisher's Exact.

Hasil: Hasil penelitian menunjukkan $14,5 \%$ balita usia $6-23$ bulan mengalami stunting, 33,3\% anak memilliki tingkat kecukupan zat besi yang kurang dan 35,7\% anak memiliki tingkat kecukupan seng yang kurang. Uji statistik menunjukkan terdapat hubungan yang signifikan antara tingkat kecukupan zat besi dan seng dengan kejadian stunting dengan $p=0,02$ dan $p=0,018$.

Kesimpulan: Proporsi stunting akan meningkat jika tingkat kecukupan zat besi dan seng inadekuat. Sebaiknya dilakukan peningkatan edukasi tentang tingkat kecukupan zat besi dan seng untuk balita usia 6-23 bulan yang bertujuan untuk mengurangi dan mencegah stunting.
\end{abstract}

Kata Kunci: stunting, tingkat kecukupan zat besi dan seng, balita 


\section{ABSTRACT}

Background: Stunting is a cronic malnutrition that affects linear growth. The main cause of malnutrition is the adequacy of micronutrients in the process of linear growth. Micronutrients that relate to stunting are iron and zinc, because both of that micronutrient have necessary role in linear growth of toddlers age $6-23$ months.

Objectives: The purpose of this study was to analyze correlation between iron and zinc adequacy level with stunting incidence in toddlers age 6-23 months.

Methods: This study was an analytical study with cross sectional design. The sample size were 55 children spread over 25 Posyandu in Suci Village. The data collected using of food recall $3 \times 24$ hours, height measurement with microtoice for stunting status, and the questionnaire characteristics of children and mothers. The data were analyzed by using Fisher's Exact test.

Result: The results showed $14.5 \%$ of toddlers age $6-23$ months were stunted. $33.3 \%$ of children were given inadequate iron intake and $35.7 \%$ of children were given inadequate zinc intake. The analysis test showed there was a significant correlation between levels of iron and zinc adequacy with the incidence of stunting with $p=0.02$ and $p=0.018$.

Conclusion: The proportion of stunting will increase if the toddler were given inadequate of iron and zinc. Education about the adequacy levels of iron and zinc for toddler age 6-23 months were adjusted to reduce and avoid stunting.

Keywords: stunting, Iron and Zinc adequacy level, toddler

\footnotetext{
* Koresponden:

enggarkartikadewi@yahoo.co.id

${ }^{1}$ Departemen Gizi Kesehatan, Fakultas

Kesehatan Masyarakat-Universitas Airlangga
}

\section{PENDAHULUAN}

Stunting merupakan masalah gizi yang menyebabkan gangguan pertumbuhan linier pada balita yang ditandai dengan nilai z-score tinggi badan menurut umur menunjukkan angka dibawah $-2 \mathrm{SD}^{1}$. Masalah ini muncul saat anak berusia 6-23 bulan ${ }^{2}$. Kekurangan gizi pada usia dini akan dapat menyebabkan meningkatnya angka kesakitan, kematian, dan postur tubuh tergolong pendek ${ }^{3}$.

Di Indonesia, prevalensi stunting relatif tinggi jika dibandingkan dengan Negara berkembang lainnya, seperti Myanmar, Vietnam, Malaysia, Thailand dan Singapore ${ }^{4}$. Prevalensi stunting di Indonesia pada tahun 2013 (37,3\%) meningkat jika dibandingkan pada tahun 2007 (36,8\%) dan $2010(35,6 \%)^{5}$. Masalah stunting dianggap sebagai masalah kesehatan dan harus segera ditangani, jika memiliki prevalensi lebih dari sama dengan $20 \%$, sehingga masalah stunting masuk ke dalam salah satu program prioritas pembangunan kesehatan dalam tahun 2015$2019^{4}$.

Faktor penyebab terjadinya stunting beragam yang mencakup kecukupan zat gizi tidak adekuat dalam jangka waktu panjang dan diperparah dengan terjadinya penyakit infeksi secara terus menerus ${ }^{6}$. Terganggunya proses pertumbuhan linier tersebut diakibatkan karena adanya adaptasi tubuh terhadap asupan yang rendah dan mengakibatkan kecukupan zat gizi yang tidak adekuat, sehingga proses metabolisme tubuh akan terganggu dan akhirnya proses terbentuknya sel atau jaringan akan terhambat ${ }^{2}$.

Asupan makanan yang rendah akan mengakibatkan kelaparan tersembunyi atau masalah gizi yang tidak kasat mata yang disebabkan karena kurangnya zat gizi mikro, seperti zat besi dan seng. Seringkali, makanan yang dikonsumsi berupa makanan yang tinggi akan karbohidrat, namun rendah akan bahan makanan seperti lauk hewani, sayur, dan buah $^{7}$. 
Pada usia dini, balita yang kekurangan zat besi dapat menyebabkan gangguan kognitif dan fisik dan peningkatan risiko kematian. Hal tersebut dikarenakan zat besi memegang peran sebagai mengedar oksigen semua jaringan tubuh. Jika oksigenasi ke jaringan tulang berkurang, maka tulang tidak akan tumbuh maksimal. Selain itu, balita yang mengalami defisiensi seng juga mudah terkena penyakit infeksi dan gangguan pertumbuhan pertumbuhan. Seng berperan untuk memproduksi hormon pertumbuhan ${ }^{8}$.

Pada tahun 2013, Kabupaten Gresik memiliki prevalensi stunting sebesar $17,6 \%$ atau sekitar 18.589 jiwa $^{9}$. Meskipun tidak diketahui angka stunting di tiap daerah, namun pada tahun 2013 angka gizi kurang di daerah Kecamatan Manyar tergolong tinggi dengan proporsi sebanyak 523 jiwa. Terdapat tiga Puskesmas yang berada diwilayah kerja Kecamatan Manyar, yaitu Puskesmas Manyar, Puskesmas Sembayat dan Puskesmas Sukomulyo. Diketahui Puskesmas Sukomulyo memiliki proporsi masalah gizi kurang terbanyak, yaitu sebanyak 207 jiwa ${ }^{10}$.

Beberapa hasil penelitian sebelumnya menunjukkan defisiensi tingkat kecukupan zat besi dan seng di dalam tubuh yang dapat menyebabkan stunting. Seperti halnya penelitian di Washington DC yang meneliti rendahnya kecukupan zat besi dan seng didalam tubuh dengan variabel bebas yaitu kadar hemoglobin, serum ferritin, dan serum zinc dengan stunting, wasting dan underweight sebagai variabel terikat ${ }^{8}$. Oleh karena itu peneliti tertarik untuk menganalisis hubungan antara kecukupan zat besi dan seng dengan kejadian stunting di Indonesia sebagai salah satu negara berkembang. Tujuan dari penelitian ini adalah untuk mengetahui tingkat kecukupan zat besi dan seng dengan kejadian stunting di wilayah kerja Puskesmas Sukomulyo Kecamatan Manyar Kabupaten Gresik.

\section{METODE}

Penelitian ini dilakukan pada bulan Juni 2017 di Desa Suci, Kecamatan Manyar, Kabupaten Gresik. Penelitian ini menggunakan pendekatan kuantitatif dengan jenis penelitian observasional analitik dan desain penelitian cross sectional. Populasi dari penelitian ini adalah anak usia 6-23 bulan yang terdapat di Desa Suci, Kecamatan Manyar, Kabupaten Gresik. Populasi tersebut dipilih karena Desa Suci merupakan Desa yang memiliki masalah gizi kurang terbanyak di Kecamatan Manyar, sebab gizi kurang yang tidak segera diatasi akan menyebabkan stunting. Besar sampel dihitung menggunakan rumus uji hipotesis untuk satu proporsi populasi dengan tingkat kemaknaan $95 \%$ dan kekuatan $90 \%$ dan diperoleh sampel sebanyak 51 anak yang tersebar di 25 Posyandu. Pengambilan sampel diambil dengan metode multistage random sampling, yaitu menentukan Desa terpilih dengan menggunakan metode cluster sampling, memilih jumlah subyek tiap posyandu dengan menggunakan metode proportionate random sampling dan memilih subyek penelitian dengan menggunakan simple random sampling.

Variabel terikat dalam penelitian ini adalah kejadian stunting pada anak usia 6-23 bulan di Desa Suci Kecamatan Manyar Kabupaten Gresik, sedangkan variabel bebas dalam penelitian ini adalah tingkat kecukupan zat besi dan seng. Penelitian ini menggunakan data primer dan sekunder. Data primer meliputi pengukuran tinggi badan dan wawancara dengan kuesioner untuk mengetahui karakteristik anak usia 6-23 bulan dan ibu serta recall $24 \mathrm{~h}$ selama 3 hari tidak dengan berturut-turut untuk menggambarkan tingkat kecukupan zat gizi. Karakteristik ibu meliputi pekerjaan, pendidikan, pengetahuan dan penghasilan. Pengukuran tinggi badan anak menggunakan microtoise dengan ketelitian $0,1 \mathrm{~cm}$. Hasil pengukuran di entry kedalam software WHO Anthro versi 3.0.1. dan akan diketahui nilai Z-score pengukuran status gizi tinggi badan menurut umur. Nilai Z-Score dibedakan menjadi dua yaitu <-2SD tergolong kategori stunting dan yang mempunyai nilai zscore $\geq-2$ SD tergolong kategori normal. Karakteristik anak yang diambil dalam penelitian ini adalah usia, jenis kelamin dan berat lahir anak, sedangkan karakteristik ibu yang diambil dalam penelitian ini adalah pekerjaan, pendidikan terakhir, pengetahuan gizi, dan penghasilan keluarga. Penilaian 
pengetahuan ibu menggunakan kuesioner $K A P^{11}$ dengan metode perhitungan total jawaban yang benar akan dibagi dengan total soal dan dikali seratus persen. Penentuan kategori dibagi menjadi tiga yang akan disesuaikan dengan kuartil saat dilapangan. Hasil recall 24h selama 3 hari tersebut akan dirata-rata dan dibandingkan dengan cut off point, yaitu < EAR untuk kategori kurang dan $\geq$ EAR untuk kategori cukup ${ }^{10}$. Data Sekunder meliputi data jumlah balita usia 6-23 bulan di Desa Suci.

Penelitian ini menggunakan analisis univariat dan bivariate. Analisis data univariat digunakan untuk mengetahui distribusi karakteristik anak dan ibu. Analisis data bivariat dilakukan untuk mengetahui hubungan kecukupan zat besi dan seng dengan kejadian stunting menggunakan uji Fisher's Exact.

Penelitian ini telah mendapatkan persetujuan dari komisi etik dari Fakultas Kesehatan Masyaraat dengan nomor 241-KEPK yang dikeluarkan tanggal 19 Mei 2017. Inform consent telah didapatkan dari masing-masing ibu yang mengasuh balita usia 6-23 bulan.

\section{HASIL DAN PEMBAHASAN}

Karakteristik balita usia 6-23 bulan yang diteliti pada penelitian ini meliputi, jenis kelamin, usia anak, dan berat badan lahir. Karakteristik balita yang ditampilkan pada tabel 1 menunjukkan bahwa jumlah sampel paling banyak adalah laki-laki, yaitu 58,2\% balita. Pada penelitian di Nigeria menyebutkan jenis kelamin dapat mempengaruhi kejadian stunting pada balita. Anak laki-laki dikatakan memiliki risiko tinggi terkena stunting karena secara fisik anak laki-laki lebih aktif sehingga cadangan energi didalam tubuh yang digunakan sebagai pertumbuhan anak akan berkurang $^{12}$. Jika dilihat dari segi usia, mayoritas responden memiliki usia 12-23 bulan (65,5\%). Semakin bertambahnya usia, maka angka stunting semakin terlihat ${ }^{13}$. Semua anak pada penelitian ini memiliki berat lahir $\geq 2500$ gram. Hal ini selaras dengan penelitian Oktarina dan Sudiarti di Sumatera yang menyebutkan sebagian besar anak pada penelitiannya memiliki berat lahir $\geq 2500$ gram $^{13}$. Bayi yang lahir dengan berat normal ( $\geq 2500$ gram) tetap berisiko terkena stunting meskipun tidak sebesar risiko bayi yang lahir dengan berat kurang (<2500 gram). Risiko ini timbul jika tingkat kecukupan zat gizi dalam tubuh anak inadekuat, pelayanan kesehatan yang tidak layak dan terjadinya penyakit infeksi secara terus menerus pada masa periode emas $^{14}$.

Tabel 1. Karakteristik Anak Usia 6-23 Bulan di Desa Suci, Kecamatan Manyar, Kabupaten Gresik

\begin{tabular}{|c|c|c|c|c|c|c|c|}
\hline \multirow{3}{*}{ Karakteristik Sampel } & & \multicolumn{4}{|c|}{ TB/U } & \multirow{2}{*}{\multicolumn{2}{|c|}{ Total }} \\
\hline & & \multicolumn{2}{|c|}{ Pendek } & \multicolumn{2}{|c|}{ Normal } & & \\
\hline & & $\mathbf{n}$ & $\%$ & $\mathbf{n}$ & $\%$ & $\mathbf{n}$ & $\%$ \\
\hline \multirow{2}{*}{ Jenis Kelamin } & laki-laki & 5 & 62,5 & 27 & 57,4 & 32 & 58,2 \\
\hline & Perempuan & 3 & 37,5 & 20 & 42,6 & 23 & 41,8 \\
\hline \multirow{3}{*}{ Usia Anak } & 6 bulan & 0 & 0 & 7 & 14,9 & 7 & 12,7 \\
\hline & 7-11 bulan & 2 & 25 & 10 & 21,3 & 12 & 21,8 \\
\hline & $12-23$ bulan & 6 & 75 & 30 & 63,8 & 36 & 65,5 \\
\hline \multirow{2}{*}{ Berat Badan Lahir } & $<2500$ gram & 0 & 0 & 0 & 0 & 0 & 0 \\
\hline & $\geq 2500$ gram & 8 & 100 & 47 & 100 & 55 & 100 \\
\hline
\end{tabular}


Tabel 2. Karakteristik Ibu yang Memiliki Anak Usia 6-23 Bulan di Desa Suci, Kecamatan Manyar, Kabupaten Gresik

\begin{tabular}{|c|c|c|c|c|c|c|c|}
\hline & \multirow{3}{*}{ Karakteristik Ibu } & \multicolumn{4}{|c|}{ TB/U } & \multicolumn{2}{|c|}{ Total } \\
\hline & & \multicolumn{2}{|c|}{ Pendek } & \multicolumn{2}{|c|}{ Normal } & \multirow[b]{2}{*}{$\mathbf{N}$} & \multirow[b]{2}{*}{$\%$} \\
\hline & & $\mathbf{n}$ & $\%$ & $\mathbf{n}$ & $\%$ & & \\
\hline \multirow{2}{*}{ Pekerjaan } & Bekerja & 2 & 25 & 9 & 19,1 & 11 & 20 \\
\hline & Tidak Bekerja & 6 & 75 & 38 & 80,9 & 44 & 80 \\
\hline \multirow{4}{*}{ Pendidikan } & PT & 3 & 37,5 & 11 & 23,4 & 14 & 25,5 \\
\hline & SMA & 4 & 50 & 33 & 70,2 & 37 & 67,3 \\
\hline & SMP & 1 & 12,5 & 3 & 6,4 & 4 & 7,3 \\
\hline & SD & 0 & 0 & 0 & 0 & 0 & 0 \\
\hline \multirow{3}{*}{ Pengetahuan } & Kurang & 3 & 37,5 & 4 & 8,5 & 7 & 12,7 \\
\hline & Cukup & 5 & 62,5 & 30 & 63,8 & 35 & 63,6 \\
\hline & Baik & 0 & 0 & 13 & 27,7 & 13 & 23,6 \\
\hline \multirow{5}{*}{$\begin{array}{l}\text { Penghasilan } \\
\text { Keluarga }\end{array}$} & Kuartil 1 (Rp. 1.500.000- Rp. 2 600.000) & 3 & 37,5 & 8 & 17 & 11 & 20 \\
\hline & Kuartil 2 (Rp. 2.600.001- Rp. 3.300.000) & 0 & 0 & 21 & 44,7 & 21 & 38,2 \\
\hline & Kuartil 3 (Rp. 3.300.001- Rp. 3.680.000) & 0 & 0 & 1 & 2,1 & 1 & 1,8 \\
\hline & Kuartil 4 (Rp. 3.680.001- Rp. 6.600.000) & 4 & 50 & 9 & 19,1 & 13 & 23,6 \\
\hline & Kuartil 5 (Rp. 6.600.001- Rp. 13.000.000) & 1 & 12,5 & 8 & 17 & 9 & 16,4 \\
\hline
\end{tabular}

Karakteristik ibu yang memiliki balita usia 6-23 bulan meliputi, pekerjaan, pendidikan terakhir, pengetahuan gizi, dan penghasilan keluarga. Karakteristik ibu yang ditampilkan pada tabel 2 menunjukkan sebanyak $80 \%$ ibu tidak bekerja. Ibu yang tidak bekerja memiliki waktu luang yang lebih besar menyiapkan makan anak dan akan lebih mudah mempengaruhi status gizi anak, namun tidak menutup kemungkinan ibu yang bekerja juga akan memiliki tanggung jawab yang lebih untuk menyiapkan makan anak dipagi hari sebelum mereka berangkat bekerja ${ }^{1}$. Persentase pendidikan tertinggi terdapat pada kelompok yang telah menamatkan SMA atau tergolong pendidikan yang tinggi yaitu sebesar $67,3 \%$. Kondisi ini akan mempengaruhi daya terima informasi mengenai gizi anak dan kemampuan ibu dalam mengasuh anak khususnya pemberian makanan untuk anak ${ }^{1}$. Ibu yang memiliki pendidikan yang tinggi akan memiliki peluang yang tinggi pula dalam mengakses, memilih, dan menerapkan pola asuh yang terbaik untuk anak sehingga status gizipun ikut meningkat ${ }^{15}$. Sebagian besar ibu memiliki pengetahuan gizi yang cukup yaitu $63,6 \%$. Pengetahuan gizi ibu merupakan awal terjadinya perubahan perilaku. Perubahan perilaku yang dimaksud adalah perilaku pada persiapan makan anak. Ibu yang memiliki pengetahuan gizi cukup dan baik cenderung akan menyediakan makan dengan jumlah dan jenis yang tepat untuk memaksimalkan pertumbuhan dan perkembangan balita di periode emasnya ${ }^{1}$. Penghasilan keluarga dibagi menjadi lima kuartil yang didapatkan dari hasil dilapangan dan diperoleh sebanyak 38,2\% memiliki penghasilan pada kuartil 2 (Rp. 2.600.001- Rp. 3.300.000) atau masih masuk kedalam penghasilan menengah kebawah, dengan asumsi jika penghasilan yang didapatkan rendah akan susah untuk mendapatkan fasilitas kesehatan, sehingga status gizi anak akan menurun ${ }^{16}$. 
Tabel 3. Tingkat Kecukupan Zat Besi dan Seng pada Anak Usia 6-23 Bulan di Desa Suci, Kecamatan Manyar, Kabupaten Gresik

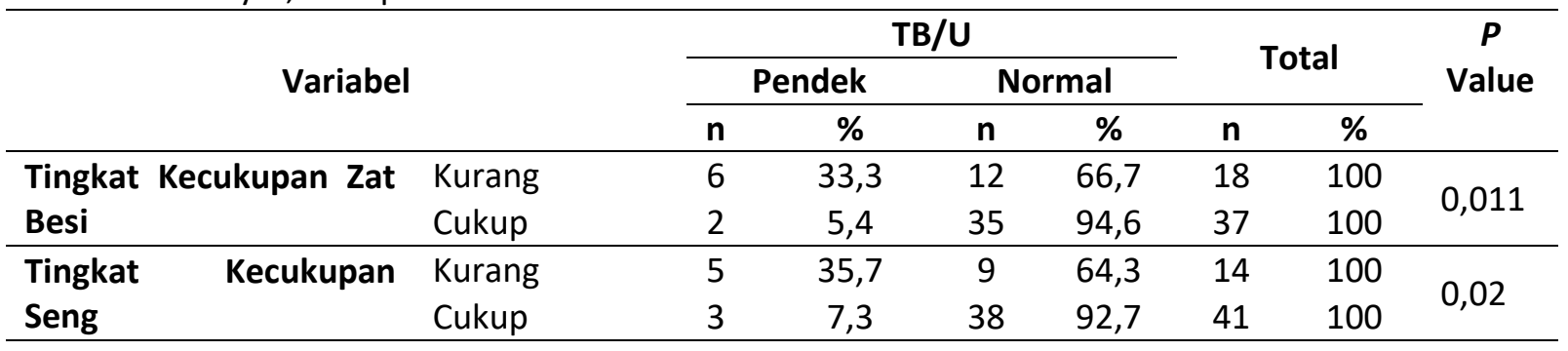

Pada Tabel 3, diketahui balita usia 6-23 bulan yang memiliki tingkat kecukupan zat besi yang inadekuat dan mengalami stunting sebanyak 33\%. Hasil uji Fisher's Exact dengan nilai $\alpha=0,05$ menunjukkan nilai $p=0,011<$ 0,05 yang memiliki arti terdapat hubungan yang signifikan antara tingkat kecukupan zat besi dengan kejadian stunting pada balita usia 6-23 bulan.

Hal ini sejalan dengan penelitian Damayanti, Muniroh dan Farapti ${ }^{6}$ pada tahun 2016 yang menyebutkan terdapat hubungan yang signifikan antara tingkat kecukupan zat besi dengan stunting. Asupan zat besi disimpan dalam otot dan sumsum tulang belakang. Jika kecukupan zat besi inadekuat, maka simpanan zat besi pada sumsum tulang belakang yang digunakan untuk memproduksi Hemoglobin $(\mathrm{Hb})$ menurun ${ }^{17}$. $\mathrm{Hb}$ berfungsi sebagai pembawa oksigen dari paru-paru keseluruh tubuh $^{18}$. Saat $\mathrm{Hb}$ menurun, eritrosit protoporfirin bebas akan meningkat yang akan mengakibatkan sintesis heme berkurang dan ukuran eritrosit akan mengecil (eritrosit mikrositik). Kondisi yang seperti ini akan mengakibatkan anemia besi ${ }^{17}$. Selain dapat menyebabkan anemia besi, defisiensi besi dapat menurunkan kemampuan imunitas tubuh, sehingga penyakit infeksi mudah masuk kedalam tubuh. Anemia besi dan penyakit infeksi yang berkepanjangan akan berdampak pada pertumbuhan linier anak ${ }^{19}$.

Pada Tabel 3, diketahui balita usia 6-23 bulan yang diberi tingkat kecukupan seng kurang dan mengalami stunting sebanyak 5 orang (35,7\%). Hasil uji Fisher's Exact dengan nilai $\alpha=0,05$ menunjukkan nilai $p=0,002<$ 0,05 yang memiliki arti terdapat hubungan yang signifikan antara tingkat kecukupan seng dengan kejadian stunting pada balita usia 6-23 bulan.

Hal ini sejalan dengan penelitian Damayanti, Muniroh dan Farapti ${ }^{11}$ pada tahun 2016 yang menyebutkan terdapat hubungan yang signifikan antara tingkat kecukupan seng dengan stunting. Seng dapat mempengaruhi pertumbuhan linier karena seng masuk kedalam nutrient tipe 2 yang dibutuhkan oleh balita usia 6-23 bulan. Nutrient tipe 2 berfungsi sebagai bahan pokok dalam pembentukan jaringan ${ }^{20}$. Seng dapat meningkatkan Insulinlike Growth Factor I (IGF I) yang akan mempercepat pertumbuhan tulang. IGF I digunakan untuk menghantarkan hormon pertumbuhan yang memiliki peran dalam suatu growth promoting factor ${ }^{21}$. Defisiensi seng juga dapat menurunkan imunitas sehingga dapat meningkatkan resiko terkena penyakit infeksi, sehingga memicu meningkatnya kebutuhan energi dan seng dan dapat menghambat pertumbuhan tulang ${ }^{22}$.

Zat besi menggunakan alat transport transferrin untuk absorpsi, namun sebagian seng juga menggunakan transferrin sebagai alat transport. Maka dari itu, asupan seng tidak boleh lebih dari asupan zat besi. Apabila asupan seng melebihi zat besi maka absorpsi seng akan terhambat dan fungsinya tidak akan berjalan seperti normalnya ${ }^{3}$.

Penelitian ini mempunyai beberapa kelebihan dan kekurangan. Kelebihannya adalah menggunakan recall $24 \mathrm{~h}$ sebanyak 3 kali secara tidak berturut-turut sehingga dapat menggambarkan tingkat asupan sehingga dapat mengetahui tingkat kecukupan pada balita. Kekurangan dari penelitian ini adalah tidak dapat ditampilkannya angka risiko terkait tingkat kecukupan zat besi dan seng dengan kejadian stunting. Hal ini dikarenakan desain 
penelitian yang digunakan, yaitu cross sectional.

\section{KESIMPULAN}

Tingkat kecukupan zat besi dan seng yang inadekuat akan berisiko mengakibatkan terhambatnya pertumbuhan linier anak. Oleh karena itu, perlu adanya peningkatan kecukupan zat besi dan seng yang adekuat. Adapun bahan makanan yang mengandung zat besi yaitu sarden, hati, telur, tomat, kedelai, daging sapi, bayam dan lain-lain. Makanan yang mengandung seng adalah bayam, brokoli, pisang, kuning telur, daging sapi, dan lain-lain.

\section{ACKNOWLEDGEMENT}

Terima Kasih kepada: Responden yang telah meluangkan waktu dan berbagi informasi dalam pelaksanaan penelitian ini. Seluruh staf Puskesmas Sukomulyo khususnya ahli gizi dan bidan desa Suci yang telah membantu dalam pelaksanaan pengambilan data.

\section{REFERENSI}

1. Aridiyah FO, Rohmawati N, Ririanty $M$. Faktor-faktor yang Mempengaruhi Kejadian Stunting pada Anak Balita di Wilayah Pedesaan dan Perkotaan. e-Jurnal Pustaka Kesehatan, vol. 3 (no. 1) Januari 2015. Available from https://jurnal.unej.ac.id/index.php/JPK/ar ticle/view/2520/2029. Diakses pada 15 September 2017

2. Sudiman H. Stunting atau Pendek: Awal Perubahan Patologis atau Adaptasi Karena Perubahan Sosial Ekonomi yang Karena Perubahan Sosial Ekonomi yang Berkepanjangan?. Media Litbang Kesehatan Volume XVIII Nomor 1 Tahun 2008. Available from https://www.ijcmas.com/6-42017/Hari\%20Mohan\%20Meena,\%20et\% 20al.pdf. Diakses pada 27 Juli 2017

3. Kusudaryati DPD. Kekurangan Asupan Besi dan Seng Sebagai Faktor Penyebab Stunting pada Anak. PROFESI Volume 10 / September 2013 - Februari 2014. Available from https://ejournal.stikespku.ac.id/index.php /mpp/article/view/66/57. Diakses pada 22 Agustus 2017

4. Kementrian Kesehatan RI. Infodatin: Situasi Balita Pendek. 2016. Available from

http://www.depkes.go.id/resources/dow nload/pusdatin/infodatin/situasi-balitapendek-2016.pdf. Diakses pada 27 Juli 2017

5. Litbang. Riset Kesehatan Dasar Dalam Angka (RISKESDAS) 2013 Provinsi Jawa Timur. 2013. Available from http://terbitan.litbang.depkes.go.id/pener bitan/index.php/lpb/catalog/book/114.

Diakses pada 10 Maret 2017

6. Damayanti RA, Muniroh L, Farapti. Perbedaan Tingkat Kecukupan Zat Gizi dan Riwayat Pemberian AS. Media Gizi Indonesia, Vol. 11, No. 1 Januari-Juni 2016: hlm. 61-69. Available from http://ejournal.unair.ac.id/index.php/MGl/article/ view/4393. Diakses pada tanggal 22 Agustus 2017

7. Sumedi E dan Sandjaja. Asupan Zat Besi, Vitamin A Dan Zink Anak Indonesia Umur 6-23 Bulan. Penelitian Gizi dan Makanan, Desember 2015 Vol. 38 (2): 167-175. Available from http://ejournal.litbang.depkes.go.id/index .php/pgm/article/download/5546/4515.

Diakses pada 14 September 2017

8. Petry N, Olofin I, Boy E, Angel MD, Rohner F. The Effect of Low Dose Iron and Zinc Intake on Child Micronutrient Status and Development during the First 1000 Days of Life: A Systematic and Meta-Analysis. Nutrients 2016, 8, 773. Available from https://www.ncbi.nlm.nih.gov/pmc/articl es/PMC5188428/pdf/nutrients-0800773.pdf. Diakses pada 14 September 2017

9. Litbang. Riset Kesehatan Dasar Dalam Angka (RISKESDAS) 2013 Provinsi Jawa Timur. 2013. Available from http://terbitan.litbang.depkes.go.id/pener bitan/index.php/lpb/catalog/book/114. Diakses pada 10 Maret 2017

10. Dinas Kesehatan Kab. Gresik. Profil Kesehatan Kabupaten Gresik Tahun 2013. 2013. Available from http://www.pusdatin.kemkes.go.id/resou 
rces/download/profil/PROFIL_KAB_KOTA_ 2013/3525_Jatim_Kab_Gresik_2013.pdf. Diakses pada tanggal 10 Maret 2017

11. http://www.fao.org/docrep/019/i3545e/i 3545e.pdf

12. Akombi BJ, Agho KE, Hall JJ, Merom D, Burt TA. Stunting And Severe Stunting Among Children Under-5 Years In Nigeria: A Multilevel Analysis. BMC Pediatrics (2017) 17:15. Available from https://www.ncbi.nlm.nih.gov/pmc/articl es/PMC5237247/pdf/12887_2016_Article _770.pdf. Diakses pada 17 September 2017.

13. Oktarina Z dan Sudiarti T. Faktor Risiko Stunting Pada Balita (24-59 Bulan) Di Sumatera. Jurnal Gizi dan Pangan, November 2013, 8(3): 175-180. Available from

http://ilkom.journal.ipb.ac.id/index.php/j gizipangan/article/viewFile/7977/6259. Diakses pada 15 Agustus 2017

14. Rahayu A, Yulidasari F, Putri AO, Rahman F. Riwayat Berat Badan Lahir dengan Kejadian Stunting pada Anak Usia Bawah Dua Tahun. Kesmas: Jurnal Kesehatan Masyarakat Nasional Vol. 10, No. 2, November 2015. Available from https://media.neliti.com/media/publicati ons/144977-ID-riwayat-berat-badan-lahirdengan-kejadia.pdf. Diakses pada 17 September 2017

15. Handani F, Siagian A, Aritonang EY, Mother's Education as A Determinant of Stunting among Children of Age 24 to 59 Months in North Sumatera Province of Indonesia. IOSR Journal Of Humanities And Social Science (IOSR-JHSS) Volume 22, Issue 6, Ver. 9 (June. 2017) PP 58-64. Available from http://www.iosrjournals.org/iosrjhss/papers/Vol.\%2022\%20lssue6/Version -9/12206095864.pdf. Diakses pada 17 September 2017

16. Ni'mah $\mathrm{K}$ dan Nadhiroh SR. Faktor Yang Berhubungan Dengan Kejadian Stunting Pada Balita. Media Gizi Indonesia, Vol. 10, No. 1 Januari-Juni 2015: hlm. 13-19
Available http://ejournal.unair.ac.id/index.php/MGl/article/ download/3117/2264. Diakses pada tanggal 22 Agustus 2017

17. Zhang J, Shi J, Himes JH, Du Y, Yang S, Shi $\mathrm{S}$, Zhang J. Undernutrition status of children under 5 years in Chinese rural areas - data from the National Rural Children Growth Standard Survey. Asia Pasific J Clin Nutrition 2011; 20(4): 584592. Available from http://apjcn.nhri.org.tw/server/APJCN/20 /4/584.pdf. Diakses pada 15 Agustus 2017

18. Lyfia D, Deliana M, Hakimi NR, Lubis B. Growth velocity in elementary school children with iron deficiency anemia after iron therapy. Paediatr Indonesia. 2009;49(5):249-52. Available from file://C:/Users/axioo/Downloads/5781160-1-SM\%20(1).pdf. Diakses pada 15 Agustus 2017

19. Soliman AT, Sanctis VD, Kalra S. Anemia and Growth. Indian Journal of Endocrinology and Metabolism 18.Suppl 1 (2014): S1-S5. Available From https://www.ncbi.nlm.nih.gov/pmc/articl es/PMC4266864/. Diakses pada 15 Agustus 2017

20. King JC. Zinc : an essential but elusive nutrient. Am J Clin Nutr. 94 (suppl):679S84S. 2011. Available from http://ajcn.nutrition.org/content/94/2/67 9S.full.pdf+html. Diakses pada 15 Agustus 2017

21. Backeljauw P. Insulin-like growth factor I deficiency. 2008. Available from http://hgfound.org/wpcontent/uploads/2015/02/Insulin-LikeGrowth-Factor-I-Deficiency.pdf. Diakses pada 16 Agustus 2017

22. Prendergast AJ, Humphrey JH. The stunting syndrome in developing countries. Paediatrics and International Child Health 2014 VOL. 34 NO. 4. Available from

https://www.ncbi.nlm.nih.gov/pmc/articl es/PMC4232245/pdf/pch-34-04-250.pdf.

Diakses pada 16 Agustus 2017. 